\title{
An Analysis of Epistemological Learning Barriers on Newton's Law Material in Engineering Class
}

\author{
Antomi Saregar ${ }^{1^{*}}$, Hani Mulyani ${ }^{2}$, Yetri ${ }^{3}$, Adyt Anugrah $^{4}$, Konstantinos Ravanis $^{5}$ \\ ${ }^{1}$ Universitas Islam Negeri Raden Intan Lampung, Indonesia \\ ${ }^{2}$ Universitas Islam Negeri Raden Intan Lampung, Indonesia \\ ${ }^{3}$ Universitas Islam Negeri Raden Intan Lampung, Indonesia \\ ${ }^{4}$ Universitas Islam Negeri Raden Intan Lampung, Indonesia \\ ${ }^{5}$ University of Patras, Greece \\ *Correspondence to: antomisaregar@radenintan.ac.id
}

\begin{abstract}
Physics learning barriers have been studied quite a lot, one of which is epistemological learning barriers. This study aims to determine the epistemological learning barriers and what the percentage of epistemological learning barriers on Newton's law material about motion in one of the engineering class at one of the vocational high school in Indonesia. Therefore, the researchers reported the results of research related to epistemological learning barriers. This research was qualitative descriptive research. The subjects of this research were 65 students with an age range of 14-15 years. The data was collected using tests and interviews, then analyzed using data reduction, data presentation, and conclusions. The data validity was determined using technical triangulation. The results of this research indicated that high epistemological barriers were found in two indicators, namely the incorrect calculation and the difficulty to determine the right calculation units on the Newton's First, Second, and Third Laws with the percentages of $88.75 \%$, $6.87 \%$, and $98.45 \%$ respectively. The average percentage epistemological learning barriers on the Newton's First Law was $61.7 \%$ within the moderate category and the average percentages of epistemological learning barriers on Newton's Second and Third Laws were $70.61 \%$ and $76.50 \%$ within the high categories. Based on these results, it can be concluded that students had difficulty calculating and determining Newton's Laws' unit of calculation. It indicated that the students experience epistemological learning barriers with a high category.
\end{abstract}

Keywords: Epistemological Learning Barriers; Newton's Law; Respondents' Ability Tests

Article info: Submitted 29 July 2020 | Revised 31 August 2020 | Accepted 8 September 2020

Recommended citation: Saregar, A., Mulyani, H., Yetri, Y., Anugrah, A., \& Ravanis, K. (2020). An Analysis of Epistemological Learning Barriers on Newton's Law Material in Engineering Class. Journal of Innovation in Educational and Cultural Research, 1(2), 77-86

\section{INTRODUCTION}

Many elements influence the efforts in mastering the concepts of physics material in schools. These elements include students, teachers, learning methods, and the environment, which can simultaneously influence the success of learning, especially in mastering the concept of material (Maghfirah et al., 2017; Nuangchalerm et al., 2019; Sugiarti \& Pribadi, 2013). Mastery of learning materials can make a significant contribution to the success of learning. The success of students in learning is supported by their ability to understand the concept of a material (Diani et al., 2016; Putri et al., 2012; Soleh et al., 2009; Widoyoko \& Rinawati, 2012).

Understanding the concept of a material can help students solve problems (Thahir et al., 2020). Also, the students can find out how to solve the problems logically. However, in reality, the students' physics problem solving has not run well because they are identified as having learning disabilities (Jhahro et al., 2018; Komariyah et al., 2018; Putri et al., 2018).

The learning barriers, according to Brousseau, are divided into three, namely ontogeny learning barriers, didactic learning barriers, and epistemological learning barriers (Brousseau, 2002). During the pre-research, it was found that $26.18 \%$ of students experienced ontogeny learning barriers, $24 \%$ of students experienced didactic learning barriers, and $49.8 \%$ of students experienced epistemological learning barriers. Therefore, students at the school were identified as having epistemological learning barriers. 
Epistemological learning barriers arise because of incomplete knowledge. The epistemological learning barriers tend to lead to mistakes due to the existing knowledge. To be able to determine the epistemological learning barriers, historical analysis approaches can be carried out, namely (1) explaining and understanding the knowledge learned, (2) understanding the use of the knowledge, (3) looking at the relationship between the concepts learned and other related concepts, (4) identifying the problems and explaining the reasons for the solutions, (5) repeating wrong answers to the same problems and the way each student understands the problems (Brousseau, 2002; Maghfirah et al., 2017; Pebriyanti et al., 2017).

Epistemological learning barriers occur if the students cannot use their knowledge of different problems. Many students solve problems without understanding what is meant by the problem so that mistakes might occur. The students usually do the exercises just by utilizing their counting capacity without analyzing what is meant by the problems (Ahmad et al., 2017; Brousseau, 2002; Yuberti et al., 2019). The inability to identify, explain, determine, and correlate the relationship between physics learning materials might cause epistemological barriers (Brousseau, 2002; Budiarti et al., 2018; Lestari et al., 2017; Maghfirah et al., 2017; Pebriyanti et al., 2017).

The researchers chose Newton's Law material because it requires a more in-depth understanding. The students sometimes do not study too hard, which causes concept errors (Nursaila \& Faridah, 2016; Saglam-Arslan \& Devecioglu, 2010; Sulistri \& Lisdawati, 2017). Besides, Newton's law is also fundamental in physics so that mastery of this material is imperative to be mastered by students (Damayanti et al., 2014; Januarifin et al., 2018; Maharani et al., 2019; Sukma et al., 2019).

The researchers have previously conducted several forms of identification of epistemological learning barriers, including identifying epistemological learning barriers in momentum and impulse material, static fluid, pressure on the liquid, the Bernoulli's principle, energy and its changes, the study of students' learning difficulties in mathematical proof in terms of epistemological aspects on the transformation geometry subject, and students' epistemological barriers in determining the domain and range of quadratic functions in high school (Budiarti et al., 2018; Lestari et al., 2017; Maghfirah et al., 2017; Pebriyanti et al., 2017; Rasmania et al., 2018; Sundawan et al., 2018). The novelty of the epistemological learning barriers discussed in this research lies in the material because it must be focused on one subject matter to determine and identify epistemological barriers. Based on the causes and consequences of the epistemological learning barriers, the researchers need to identify the epistemological learning barriers on Newton's Law material.

\section{METHODS}

The method and design used in this research were the descriptive-qualitative methods with case study design. Descriptive research in this research plays a role in describing and answering questions on the current issues by investigating symptoms or analyzing the relationships between several variables (Yuberti \& Saregar, 2017). The qualitative method is used to examine the natural conditions of objects with the researchers as the key instruments. The qualitative research procedure will produce descriptive data in the form of written and oral taken from the observed people (Suwandi \& Basrowi, 2008). The case study design was used to examine in detail a situation or space to store documents on certain events where the boundaries between phenomena and contexts do not appear explicitly (Syamsuddin, 2009; Yin, 2009).

\section{Participants}

The subjects of the research were 65 students in one of the vocational high school in Indonesia with an age range of 14-15 years. The samples were selected through a purposive sampling technique, which is a selection caused by particular purposes or, in other words, the deliberate selection of samples (Creswell, 2008; Sugiyono, 2016; Tongco, 2007).

\section{Instrument}

The instrument used to collect research data was in the form of a test, namely the written tests in the form of a description, which consisted of 3 questions of essential material of Newton's Law. The test was given to the students who have studied Newton's Law. The stages of the research are illustrated in Figure (Ahmad et al., 2017), 


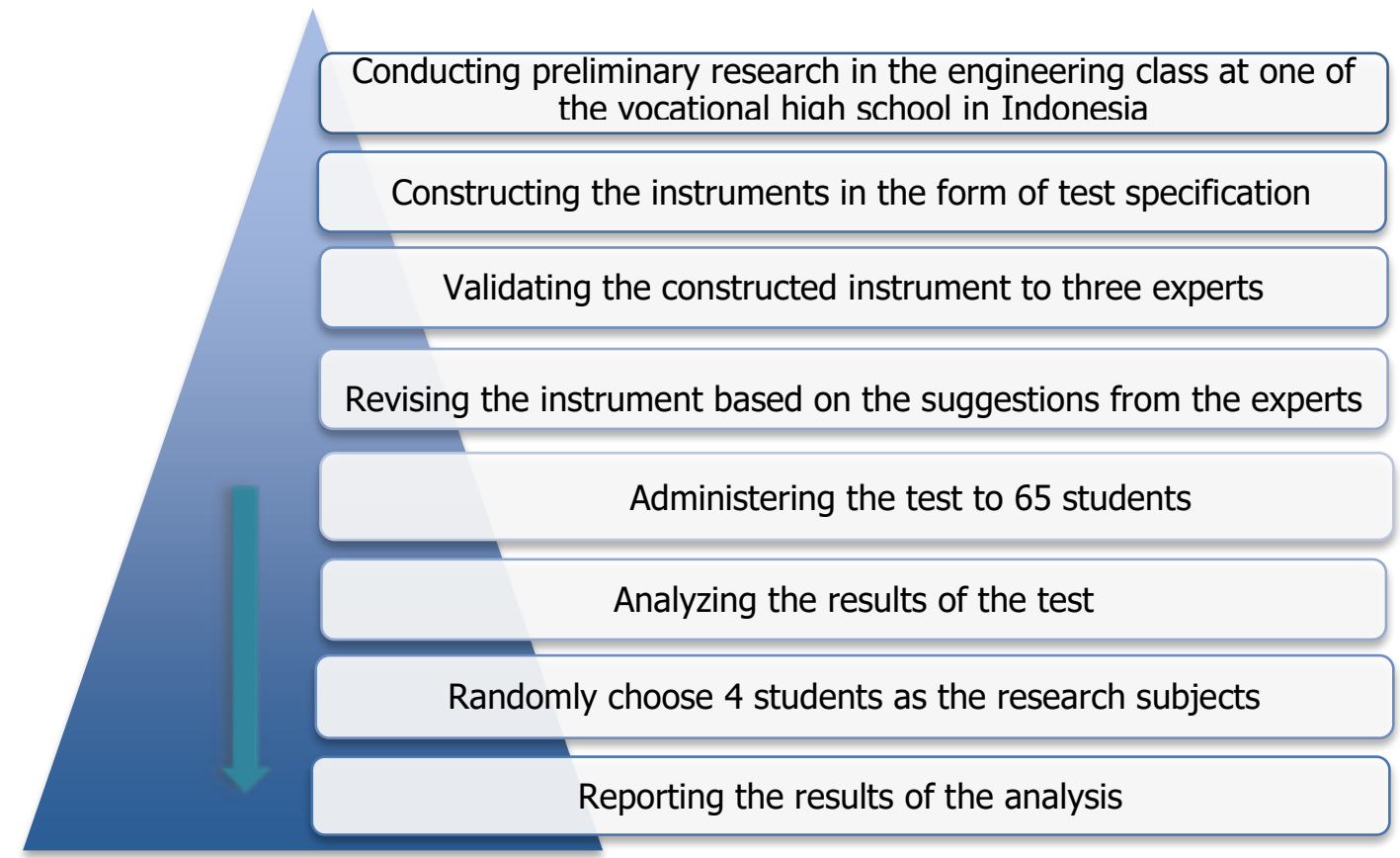

Figure 1. The Research Procedure

\section{Data Collection}

In this method, the triangulation technique was applied to the data that had been inductively collected (Sugiyono, 2016). The data analysis techniques consisted of data reduction, data presentation, and conclusions.

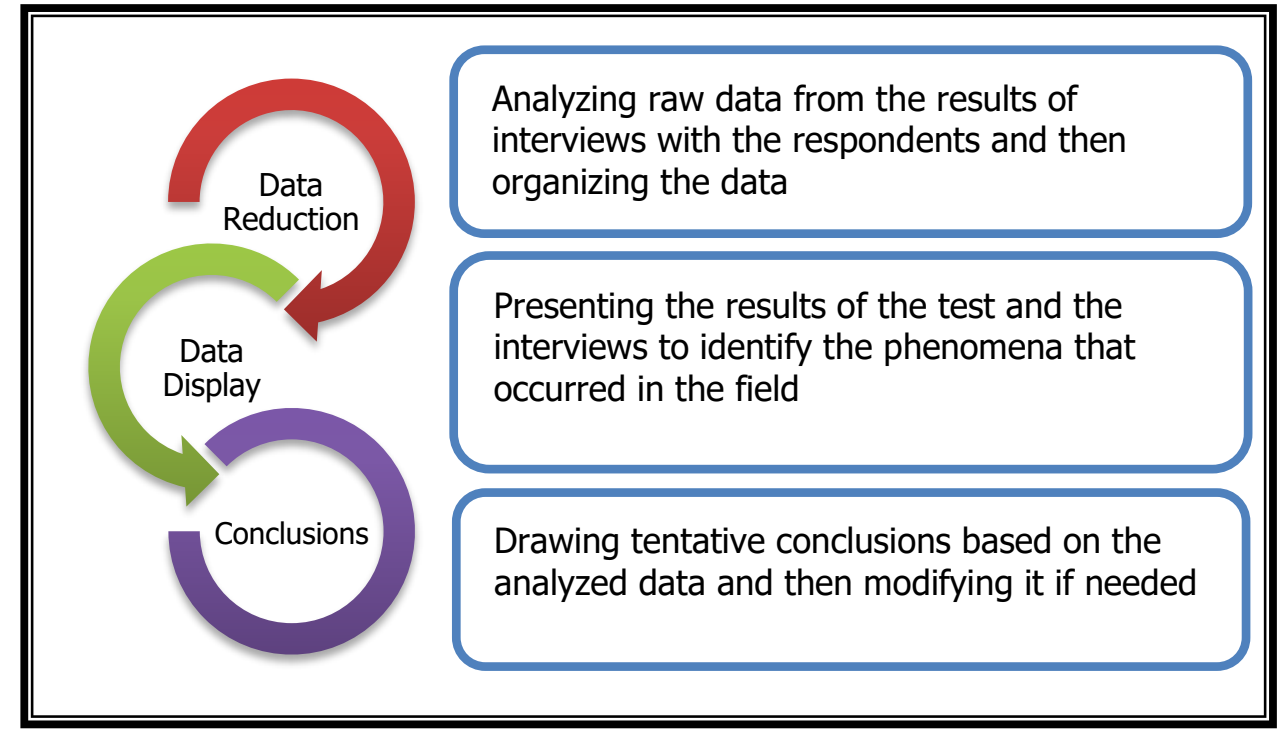

Figure 2. Data Analysis Procedure

\section{Data Analysis}

The validity of the data was determined via the triangulation technique. It was done by checking the same sources or research subjects but with a different technique, specifically by looking at the results of the test and the interview.

\section{RESULT AND DISCUSSION}

Based on the results of the test on Newton's Law material, the percentages of epistemological learning barriers in each Newton's Law were determined. The results can be seen in Table 1, Table 2, and Table 3. 
Table 1. The Percentage of Epistemological Learning Barriers Based on the Test on Newton's First Law

\begin{tabular}{lcc}
\hline \multicolumn{1}{c}{ Barriers } & Percentage & Category \\
\hline Cannot mention the physical quantities of the problems & $41.59 \%$ & Low \\
Incorrect identification of the physical quantities of the problems & $41.59 \%$ & Low \\
Incorrect use of equation in Newton's First Law & $40.67 \%$ & Low \\
Calculation errors & $88.75 \%$ & Very High \\
Unable to determine the exact physical units & $88.75 \%$ & Very High \\
Unable to explain the relationship between Newton's force and gravity & $70.62 \%$ & High \\
Average score & $61.7 \%$ & Moderate \\
\hline
\end{tabular}

Based on Table 1, it can be seen that the students' highest epistemological learning barriers were found on the calculation errors and the inability to determine the exact physical quantities. The average percentage of epistemological learning barriers on Newton's First Law material was $61.7 \%$ within the moderate category. The data percentage can be seen in the following figure;

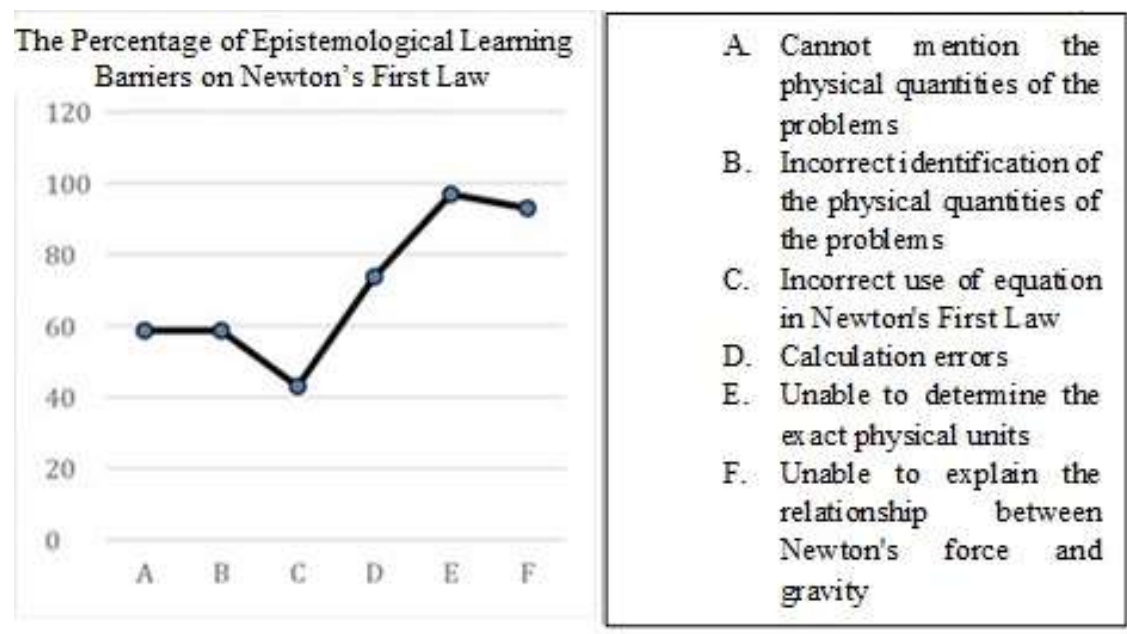

Figure 3. Percentage of Epistemological Learning Barriers on Newton's First Law

Table 2. The Percentage of Epistemological Learning Barriers Based on the Test on Newton's Second Law

\begin{tabular}{lrc}
\hline Barriers & Percentage & Category \\
\hline Cannot mention the physical quantities of the problems & 58.61 & Moderate \\
Incorrect identification of the physical quantities of the problems & 58.61 & Moderate \\
Incorrect use of equation in Newton's Second Law & 43.01 & Low \\
Calculation errors & 73.71 & High \\
Unable to determine the exact physical units & 96.87 & Very High \\
Unable to explain the relationship between acceleration and force & 92.96 & Very High \\
Average & 70.61 & High \\
\hline
\end{tabular}

Based on Table 2, it was known that the highest epistemological learning barriers could be found in the "unable to determine the exact physical quantity for acceleration" with a percentage of $96.87 \%$. The average percentage of epistemological learning barriers on Newton's second law was $70.61 \%$ with a high category. The percentage of epistemological learning barriers can be seen in the following Figure 4. 


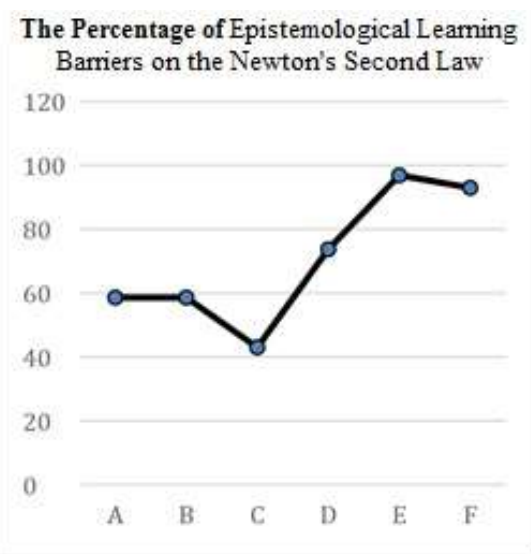

A Cannot mention the physical quantities of the problems

B. Incorrect identification of the physical quantities of the problems

C. Incorrect use of equation in Newtor's Second L aw

D. Calculation errors

E. Unable to determine the exact physical units

F. Unable to explain the relationship between acceleration and force

Figure 4. The Percentage of Epistemological Learning Barriers Based on Newton's Second Law

Table 3. The Percentage of Epistemological Learning Barriers Based on the Test on Newton's Third Law

\begin{tabular}{lrc}
\hline \multicolumn{1}{c}{ Barriers } & Percentage & Category \\
\hline Cannot mention the physical quantities of the problems & 53.81 & Low \\
Incorrect identification of the physical quantities of the problems & 53.81 & Low \\
Incorrect use of equation in Newton's Third Law & 72.15 & High \\
Calculation errors & 98.45 & Very High \\
Unable to determine the exact physical units & 98.45 & Very High \\
Cannot explain the relationship between the force and tension of the rope and the & 82.38 & Very High \\
gravity & & \\
$\quad$ Average & 76.50 & High \\
\hline
\end{tabular}

Based on Table 3, the highest epistemological learning barrier can be found in the calculation errors and cannot determine the exact unit for Newton's acceleration with a percentage of $98.45 \%$. The average percentage of epistemological learning barriers was $76.50 \%$ within a high category. The percentages can be seen in the following Figure 5.

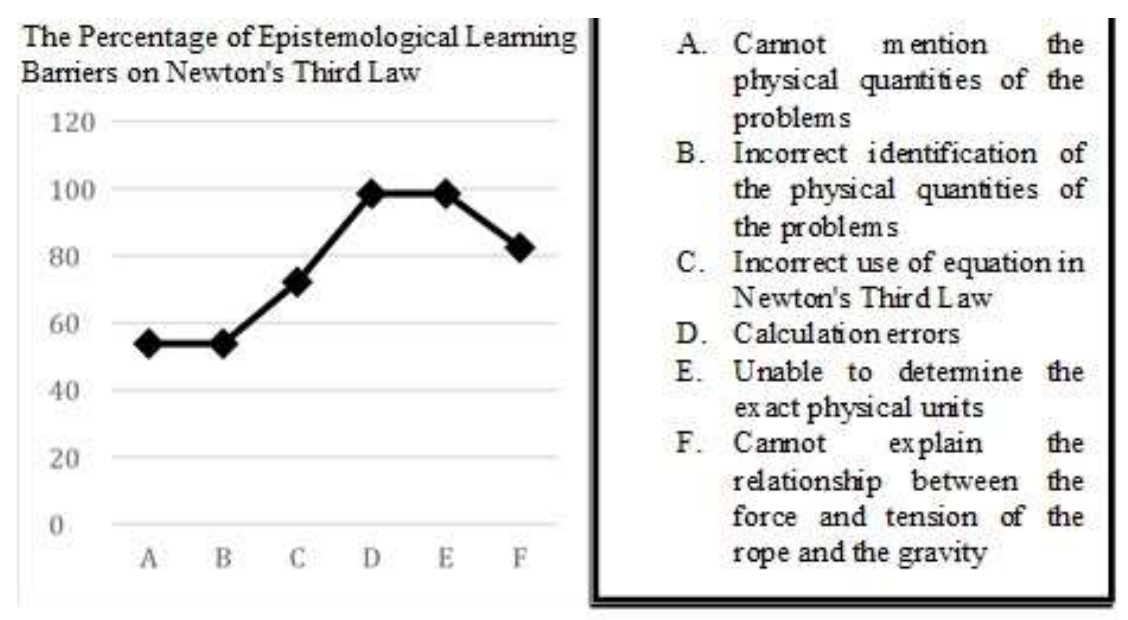

Figure 5. The Percentage of Epistemological Learning Barriers Based on Newton's Third Law

Based on the research analysis of epistemological learning barriers on Newton's Law material, very high categories of epistemological barriers were found, namely (1) In the Newton's First Law, the barriers were found the calculations error, and in determining the exact unit in calculations; (2) In Newton's Second Law, the barriers were found in determining the exact unit of calculation and in explaining the relationship between acceleration and force; and (3) In Newton's Third Law, the barriers were found in the calculation errors, in determining the right unit for Newton's acceleration and force, and in explaining the relationship between the force and tension of the rope and gravity. The interviews with four randomly selected students were conducted to clarify the data obtained after analyzing the diagnostic test results. The results are presented in the following discussion. 


\section{Epistemological Learning Barriers On Newton's First Law}

The average student experienced epistemological learning barriers in calculation errors and in determining the exact unit of calculation (see Table 1). Of the four subjects, 2 of them experienced learning barriers in calculation errors and determining the exact unit of calculation. One subject provided unsatisfactory answers, and one other subject provided partially correct answers.

It was found after interviewing the four subjects, and they only focused on the formula without knowing the purpose of the problem so that they had difficulty in analyzing the problems and applied the incorrect formula when answering the problem. The incorrect students' answers affected their ability to determine the right unit to solve the problems, indicated that the students experienced epistemological learning barriers. The following figure displays the problem and a description of the students' answers on Newton's First Law material.

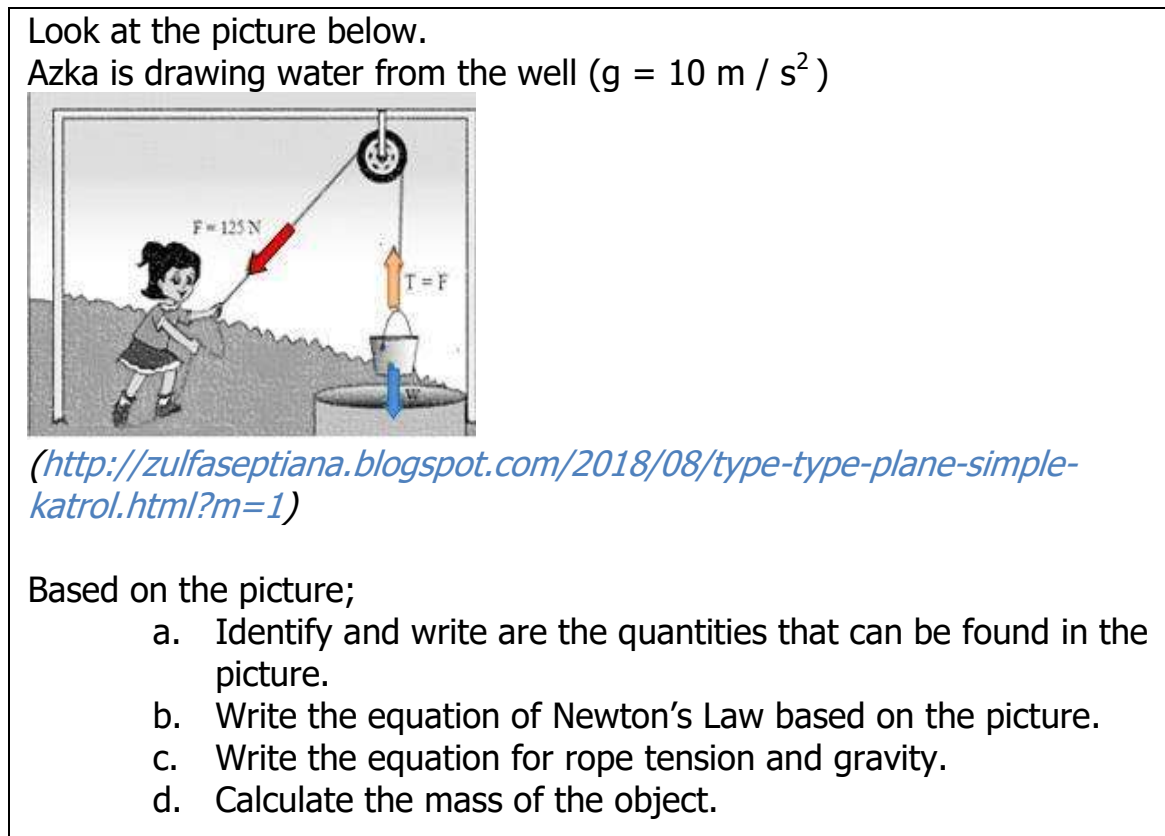

Figure 6. A Problem on Newton's First Law Material

Student A provided a wrong answer for question number 1.d. Student A was unable to do calculations on the problem and used incorrect formula is working on the problem. The incorrect answers misled the student in determining the correct unit of the calculation. Student A was unable to do the calculation. Therefore, student A was identified as having epistemological learning barriers (Rasmania et al., 2018). The average percentage of epistemological learning barriers in Newton's First Law material was $61.7 \%$ within a moderate category.

\section{The Epistemological Learning Barriers on Newton's Secon Law}

The epistemological barriers were very high because the students cannot determine the exact unit for the acceleration. The students also cannot explain the relationship between acceleration and force (see Table 2). After conducting the interviews with four respondents, it was found that some of them could solve the problems. However, many of them made errors in determining the unit of acceleration. They were confused when asked to explain the relationship between acceleration and force. Similar to the case in Newton's First Law, the students fixated on using formulas without knowing the concept. From these statements, the students failed to identify the problem, failed to explain the reasons for the solution, and unable to see the relationship between the concepts with other related concepts. The following is the question and the descriptions of answers of the student with the highest epistemological learning barriers on Newton's Second Law material. 


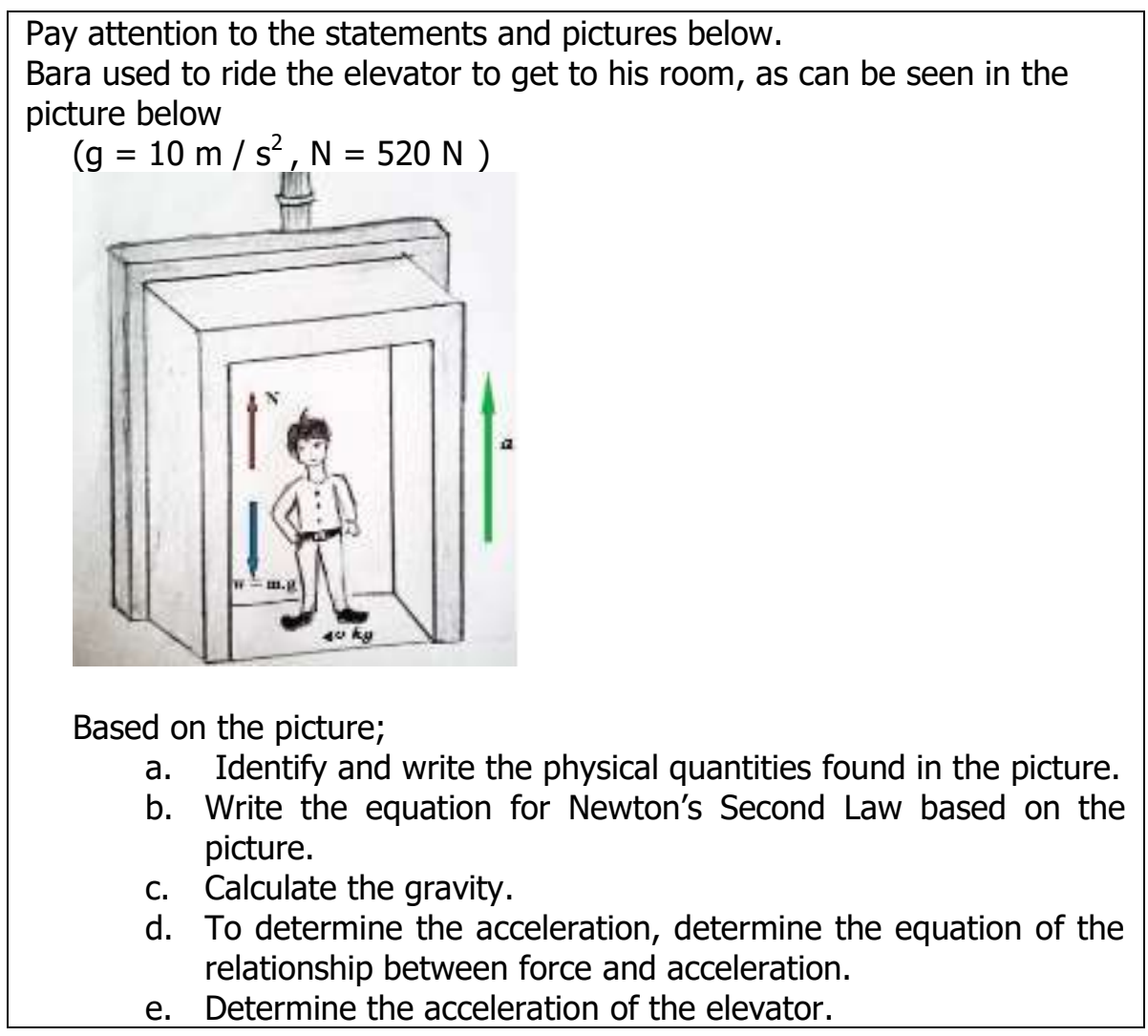

Figure 7. A Problem on Newton's Second Law Material

Student $C$ experienced the highest epistemological learning barriers. Based on his answer to question number 2.e, he could not perform the correct calculation because student $C$ answered incorrectly in the previous question. Therefore $\mathrm{C}$ performed incorrect calculation and was incorrect in determining the unit of the calculations. Meanwhile, student B solved the problems, although he was wrong in determining the unit for acceleration. The average percentage of epistemological learning barriers on Newton's Second Law was $70.61 \%$.

\section{The Epistemological Learning Barriers on Newton's Third Law}

The highest epistemological learning barriers experienced by the students were the errors in calculation and unable to determine the exact unit for Newton's acceleration and force. From the four subjects, three subjects made errors in calculation and were unable to determine the right unit while one subject was not good enough to solve the problem. Based on the analysis of students' answers and interviews, they revealed that they had difficulty in understanding the instructions. The evidence is their answers where they used the wrong formula, which led them to make a mistake in determining the right unit. From this analysis, the epistemological learning barriers occurred because the students failed to understand and apply the concepts they have learned. The following is the question and descriptions of answers of the students with the highest epistemological learning barriers on Newton's Third Law material. 
Pay attention to the statements and pictures below.

The Atwood machine, as shown in the picture, consists of a smooth cylindrical pulley without friction with a mass of $10 \mathrm{~kg}$. $\left(\mu_{\mathrm{k}}=0.1, \mathrm{~g}=10 \mathrm{~m}\right.$ $\left./ \mathrm{s}^{2}\right)$

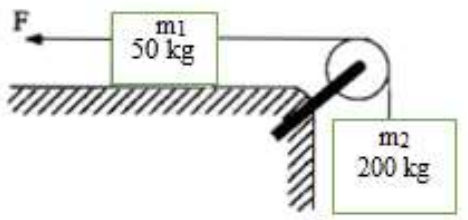

Based on the picture;

a. Identify and write the physical quantities found in the picture.

b. Determine the equation for rope tension by reviewing $\mathrm{m}_{1}$.

c. Write the equation for the relationship between rope tension and gravity to find the acceleration by reviewing $\mathrm{m}_{2}$.

d. Calculate the acceleration.

e. Calculate the rope tension.

Figure 8. A Problem on Newton's Third Law Material

In problem 3.d, the students were expected to calculate the acceleration. The students could not determine Newton's Third Law by incorrectly calculating the problem and cannot determine the right unit for force and acceleration. Student D cannot answer correctly because, based on the previous problem that required him to find the equation, he cannot determine the equation not to perform the calculation correctly. Student $D$ performed incorrect calculations and used a different formula.

In problem 3.e, the students were expected to calculate the rope tension. The indicator of the epistemological learning barrier was to explain and understand the concepts learned where the students were unable to determine Newton's Third Law by performing incorrect calculations and cannot determine the right unit of calculation. Based on his answer, student $D$ could nod provide the correct answer because, in the previous problem, he was unable to determine the relationship between the equations. It indicated that the students experienced epistemological learning barriers (Maghfirah et al., 2017). The average percentage of epistemological learning barriers on Newton's Third Law material was 76.50\%.

Based on the results of the analysis, the epistemological learning barriers experienced by the students' were caused by their imperfect understanding of the concepts (Pebriyanti et al., 2017). Epistemological learning barriers can cause difficulty understanding the next material and the difficulty in processing and solving problems. Thus, treatments need to be done to overcome or minimize these epistemological learning barriers.

\section{CONCLUSION}

Based on the results of the test on Newton's Law material, it can be concluded that in Newton's First Law, the highest epistemological learning barriers were found in the incorrect calculation and inability to determine the exact unit when working on the problem. The percentage of epistemological learning barriers was $88.75 \%$. In Newton's Second Law material, the highest epistemological learning barrier was found in determining the right unit for acceleration. The percentage of epistemological learning barriers was $96.87 \%$. The highest epistemological learning barriers on Newton's Third Law can be found in determining the right unit for Newton's acceleration and force. The percentage of epistemological learning barriers was $98.45 \%$.

The average percentage of the epistemological barriers in the engineering class of one of the vocational high schools on Newton's First Law was $61.7 \%$ within the moderate category, on Newton's Second Law was $70.61 \%$ within the high category, and on Newton's Third Law was $76.50 \%$ within the high category. Based on the results of the study, it can be suggested that students should study physics in-depth and continue to sharpen their knowledge by always practicing calculation work. The teacher is expected to compile a learning design that can anticipate the barriers experienced by the students so that they can follow the learning process effectively and efficiently 


\section{REFERENCES}

Ahmad, D., Nurhazizah, \& Sugiatno. (2017). Mengatasi Hambatan Belajar Problem Solving Matematis Siswa dengan Antisipasi Didaktis di Sekolah Menengah Pertama. Jurnal Pendidikan Dan Pembelajaran Untan, 6(1), 1-16.

Brousseau, G. (2006). Theory of didactical situations in mathematics: Didactique des mathématiques, 1970-1990 (Vol. 19). Springer Science \& Business Media.

Budiarti, A., Rusnayati, H., Siahaan, P., \& Wijaya, A. F. C. (2018). Profil Hambatan Balajar Epistimologis Siswa Pada Materi Momentum Dan Impuls Kelas X Sma Berbasis Analisis Tes Kemampuan Responden. WaPFi (Wahana Pendidikan Fisika), 3(1), 35-42.

Creswell, J. W. (2008). Research Design, Pendekatan Kualitatif, Kuantitatif, dan Mixed. Pustaka Pelajar.

Damayanti, O. P., Putri, M. A., \& Wardani, H. (2014). Pengaruh Konformitas Teman Sebaya dan Kecerdasan Emosional Terhadap Sikap Seks Pranikah pada Remaja. Mind Set, 6(1), 27-34.

Diani, R., Yuberti, Y., \& Syafitri, S. (2016). Uji Effect Size Model Pembelajaran Scramble dengan Media Video Terhadap Hasil Belajar Fisika Peserta Didik Kelas X MAN 1 Pesisir Barat. Jurnal Ilmiah Pendidikan Fisika Al-Biruni, 5(2), $265-275$.

Januarifin, D., Parno, P., \& Hidayat, A. (2018). Kesalahan siswa SMA dalam memecahkan masalah pada materi Hukum Newton. Momentum: Physics Education Journal, 2(2), 47-55.

Jhahro, K. F., Trapsilasiwi, D., \& Setiawan, T. B. (2018). Pemahaman Konsep Siswa Pada Pemecahan Masalah Soal Geometri Pokok Bahasan Segiempat Ditinjau Dari Gaya Kognitif Reflektif-Impulsif Siswa. Kadikma, 9(1), 116-122.

Komariyah, S., Afifah, D. S. N., \& Resbiantoro, G. (2018). Analisis Pemahaman Konsep Dalam Memecahkan Masalah Matematika Ditinjau Dari Minat Belajar Siswa. SOSIOHUMANIORA: Jurnal Ilmiah Ilmu Sosial Dan Humaniora, 4(1), 1-8.

Lestari, K. M., Rusnayati, H., \& Wijaya, A. F. C. (2017). Profil hambatan belajar epistimologis siswa kelas VIII smp pada materi tekanan zat cair melalui tes kemampuan responden. Prosiding Seminar Nasional Fisika (E-Journal), 6(1), 3138.

Maghfirah, Y., Rusnayati, H., \& Wijaya, A. F. C. (2017). Profil hambatan belajar epistimologis siswa kelas VIII smp terhadap materi energi dan perubahannya berbasis analisis tes kemampuan responden. Prosiding Seminar Nasional Fisika (EJournal), 6(1), 9-16.

Maharani, L., Rahayu, D. I., Amaliah, E., Rahayu, R., \& Saregar, A. (2019). Diagnostic Test with Four-Tier in Physics Learning: Case of Misconception in Newton's Law Material Diagnostic Test with Four-Tier in Physics Learning: Case of Misconception in N ewton 's Law Material. Journal of Physics Conferences Series, 1155(1), 1-9.

Nuangchalerm, P., Sagala, R., Saregar, A., \& Ellslami, R. A. Z. (2019). Environment-Friendly Education as A Solution to Against Global Warming: A Case Study at Sekolah Alam Lampung, Indonesia. Journal for the Education of Gifted Young Scientists, 7(2), 85-97.

Nursaila, A., \& Faridah, I. (2016). A Preliminary Study of Students' Problems on Newton's Law. International Journal of Business and Social Science, 7(4), 133-139.

Pebriyanti, G. W., Imansyah, H., Wijaya, A. F. C., \& Rusnayati, H. (2017, October). Profil Hambatan Belajar Epistimologis Siswa Pada Materi Asas Bernoulli Kelas XI SMA Berbasis Analisis Tes Kemampuan Responden. In Prosiding Seminar Nasional Fisika (Vol. 6, pp. SNF2017-OER).

Putri, N. S., Hartoyo, A., \& Jamiah, Y. (2018). Desain didaktis melalui naïve geometri untuk mengatasi hambatan epistemologis dalam persamaan kuadrat di SMA. Jurnal Pendidikan Dan Pembelajaran Khatulistiwa, 7(9), 1-11.

Putri, P. M., Mukhni, \& Irwan. (2012). Pemahaman Konsep Matematika Pada Materi Turunan Melalui Pembelajaran Teknik Probing. Jurnal Pendidikan Matematika, 1(1), 3-6.

Rasmania, R., Sugiatno, S., \& Suratman, D. (2018). Hambatan Epistimologis Siswa Dalam Menentukan Domain Dan Range Fungsi Kuadrat Di Sekolah Menengah Atas. Jurnal Pendidikan Dan Pembelajaran Khatulistiwa, 7(7), 1-9.

Saglam-Arslan, A., \& Devecioglu, Y. (2010). Student teachers' levels of understanding and model of understanding about Newton's laws of motion. Asia-Pacific Forum on Science Learning and Teaching, 11(1), 1-20.

Soleh, A., Pramono, \& Suratno. (2009). Faktor-Faktor Yang Mempengaruhi Keberhasilan Siswa Kelas 2 Tmo Smk Texmaco Semarang Pada Mata Diklat Service Engine Dan Komponen-Komponennya. Jurnal Pendidikan Teknik Mesin, 9(2), 57-64.

Sugiarti, R., \& Pribadi, A. S. (2013). Analisis faktor yang mempengaruhi keberhasilan belajar siswa slow learner di Sekolah Luar Biasa (SLB) negeri Semarang. WACANA, 5(1), 1-17.

Sugiyono. (2016). Metode Penelitian Kuantitatif, Kualitatif dan R \& D. Bandung: Alfabeta.

Sukma, T. A., Mundilarto, M., \& Putri, N. D. (2019). Local wisdom-Based Electronic Book on Newton's Law. Jurnal Ilmiah Pendidikan Fisika Al-Biruni, 8(2), 197-206.

Sulistri, E., \& Lisdawati, L. (2017). Using three-tier test to identify the quantity of student that having misconception on newton's laws of motion concept. Jurnal Ilmu Pendidikan Fisika, 2(1), 4-6.

Sundawan, M. D., Dewi, I. L. K., \& Noto, M. S. (2018). Kajian kesulitan belajar mahasiswa dalam kemampuan pembuktian matematis ditinjau dari aspek epistemologi pada mata kuliah geometri transformasi. Inspiramatika: Jurnal Inovasi 
Pendidikan Dan Pembelajaran Matematika, 4(1), 13-26.

Suwandi, \& Basrowi. (2008). Memahami Penelitian Kualitatif. Bandung: Rineka Cipta.

Syamsuddin. (2009). Manajemen Keuangan Perusahaan. Jakarta: PT. Raja Grafindo Persada.

Thahir, A., Anwar, C., Saregar, A., Choiriah, L., Susanti, F., \& Pricilia, A. (2020). The Effectiveness of STEM Learning: Scientific Attitudes and Students ' Conceptual Understanding. Journal of Physics: Conference Series, 1467(1), 1-9.

Tongco, M. D. C. (2007). Purposive sampling as a tool for informant selection. Ethnobotany Research and Applications, 5 , 147-158.

Widoyoko, S. E. P., \& Rinawati, A. (2012). Pengaruh Kinerja Guru Terhadap Motivasi Belajar Siswa. Cakrawala Pendidikan, 5(2), 278-289.

Yin, R. K. (2009). Case study research: Design and Methods (4th ed.). UK: Sage Publications.

Yuberti, Latifah, S., Anugrah, A., Saregar, A., Misbah, \& Jermsittiparsert, K. (2019). Approaching Problem-Solving Skills of Momentum and Impulse Phenomena Using Context and Problem-Based Learning. European Journal of Educational Research, 8(4), 1217-1227.

Yuberti, \& Saregar, A. (2017). Pengantar Metodelogi Penelitian Pendidikan Matematika dan Sains. Aura publishing 